\title{
USING OF LIMESTONE FILLER AND FLY ASH AS PARTIAL SUBSTITUTION OF CEMENT IN CONCRETE
}

\author{
Leilla-Luciana Vago ${ }^{1}$ \\ Sorin $\operatorname{Dan}^{2}$ \\ Maura Vioreanu ${ }^{3}$
}

UDK: 666.972.11

DOI: 10.14415/konferencijaGFS2018.022

Summary: In order to have a cleaner environment and to reduce emissions of $\mathrm{CO}_{2}$ people are interested in the development of new ternary cements with low fly ash content (max 30\%) and high limestone filler content (max 65\%). Limestone filler due to its chemical and physical effect (interaction with aluminates) could give rise to a synergetic effect when it is used with fly ash. Despite the fact that the use of fly ash as a cement replacement material increases the long term strength and durability of the concrete, on early ages the strength of fly ash concrete is low, so we have to accelerate the pozzolanic properties of fly ash. This study is investigating the strength of ternary cements (clinkerfly ash-limestone filler) CEM 1v2 (30 V $65 \mathrm{~K} 5 \mathrm{LL}$ ) and CEM 12v2 (30 V $35 \mathrm{~K} 35 \mathrm{LL})$ at early age containing three kinds of activators - $\mathrm{CaSO}_{4}$ (sulphate), $\mathrm{Na}_{2} \mathrm{SO}_{4}$ (sulphate+alkali) and $\mathrm{NaOH}$ (alkali) in different proportions.

Keywords: ternary cements, low fly ash, high limestone filler, pozzolanic.

\section{INTRODUCTION}

Concrete is the most used construction material in the world (after water).It consists mainly of cement (binder),fine and coarse aggregates and water. However, the production of clinker (K), the main constituent of Portland cement, induces the emission of important amounts of greenhouse gas( 5 to 8\%).In order to answer to the request of $\mathrm{CO}_{2}$ reduction and the criteria of sustainable construction, the European cement industry is interested in the development of new ternary cements with high limestone filler contents and low fly ash contents.

On the other hand, building contractors, producers of ready-mixed concrete and companies of precast concrete require that high performances of cements and durability are maintained: to guarantee minimum strength at early age and durability characteristics, when using less clinker, is the main challenge of the future [1].

\footnotetext{
${ }^{1}$ Leilla-Luciana Vago, Civ.Eng., Politehnica University Timisoara, Civil Engineering Faculty, Str. T. Lalescu, No. 2, Timisoara, Romania

${ }^{2}$ Sorin Dan, Assoc.Prof.Dr.Civ.Eng., Politehnica University Timisoara, Department of Civil Engineering and Building Services Engineering, Str. T. Lalescu, No. 2, Timisoara, Romania, tel: +40256403933, e-mail: sorin.dan@upt.ro

${ }^{3}$ Maura Vioreanu, Civ.Eng., Politehnica University Timisoara, Civil Engineering Faculty, Str. T. Lalescu, No. 2, Timisoara, Romania, e-mail: vioreanum@yahoo.com
} 
6.

МЕЂУНАРОДНА КОНФЕРЕНЦИЈА

Савремена достигнућа у грађевинарству 20. април 2018. Суботица, СРБИЈА

The fly ash reactivity at early age is relatively slow. In order to have sufficient early strength development at high replacement levels, different activation options were looked into. Limestone filler addition accelerates the hydration of cement. This accelerating effect gives rise to higher compressive strength at early age [2]. A number of studies are talking about the activation of the fly ash using chemical activators. It exist two big categories of chemical activators alkalis and sulphates. Alkaline activation involved the breaking down of the glass phases in an elevated alkaline environment to accelerate the reaction [3]. Sulphate activation is based on the ability of sulphates to react with aluminium oxide in the glass phase of fly ash to form sulphates (AFt) that contributes to strength at early ages [4].

We have chosen three kinds of activators in three different proportions to see which one is better and two types of cement CEM 1v2, CEM 12v2

- $\mathrm{CaSO}_{4}-7 \%, 10 \%, 13 \%$ by mass of the binder (as ground powder )

- $\mathrm{Na}_{2} \mathrm{SO}_{4}-1 \%, 3 \%, 5 \%$ by mass of the binder (dissolved in water)

- $\mathrm{NaOH} 8 \mathrm{M}-15 \%, 20 \%, 25 \%$ by mass of the binder (dissolved in water)

\section{EXPERIMENTAL PROGRAM}

Raw materials used for preparing these mortars are binders CEM 1v2 - 30V 65K 5LL and CEM 12v2 - 30V 35K 35LL (Table 1); 450 gr each for 3 specimens, 1350 gr sand; $225 \mathrm{ml}$ water for each mixture (we are working with volume because we could have water with solution so density increase; if density increases the mortar could be more liquid or drier).

Totally we had to do 40 mixtures (Table 2).

Table 1 - Binder composition

\begin{tabular}{|l|c|c|c|}
\hline \multirow{2}{*}{ Name } & \multicolumn{3}{|c|}{ Composition } \\
\cline { 2 - 4 } & $\begin{array}{c}\text { Clinker (K) } \\
{[\%]}\end{array}$ & $\begin{array}{c}\text { Fly ash (V) } \\
{[\%]}\end{array}$ & $\begin{array}{c}\text { Limestone filler (LL) } \\
{[\%]}\end{array}$ \\
\hline CEM 1v2 & 65 & 30 & 5 \\
\hline CEM 12v2 & 35 & 30 & 35 \\
\hline
\end{tabular}

Table 2 - Composition for a mixture without activator

\begin{tabular}{|l|c|}
\hline Mortar & $2+1$ specimens \\
\hline Binder & $\begin{array}{c}\text { CEM } \\
\text { Theory }\end{array}$ \\
\hline Binder & $450 \mathrm{gr}$ \\
\hline $\mathrm{H}_{2} \mathrm{O}+$ Activator & $225 \mathrm{ml}$ \\
\hline Sand & $1350 \mathrm{gr}$ \\
\hline (Activator) & 0 \\
\hline TOTAL & $2025 \mathrm{gr}$ \\
\hline
\end{tabular}

\section{Mortar preparation}

Before mixing the mortars, all ingredients were weighted independently. The mixture was preparing following the next steps: 
Contemporary achievements in civil engineering 20. April 2018. Subotica, SERBIA

- Water + cement mixed together in a steel container with the masticator at first gear for 30 seconds. (The activator $\mathrm{Na}_{2} \mathrm{SO}_{4}$ and $\mathrm{NaOH}$ was dissolved into water first and then mixed with dry materials; $\mathrm{CaSO}_{4}$ activator was mixed with the cement and after dissolved into the water.)

- $\quad$ Add sand in the container and mix with the masticator at first gear for another 30 seconds.

- $\quad$ After putting the sand in the container, we mixed everything at second gear another 30 seconds.

- Stop the mix and clean the container walls with a palette knife for 1' and 30"

- $\quad$ Mix everything at the second gear for 1 minute. Total time: 4 minute

All the procedures and the devices used were according to EN 196-1/2005 [5].

Were used the following tools: - masticator; scale; stopwatch; steel container

\section{Moulding the samples}

After the mortar was obtained, it was moulded in steel moulds (Figure1).Then, the mortar was compacted in moulds with shocks applied for one minute with a shocking table with the same characteristics like in EN 196-1/2005

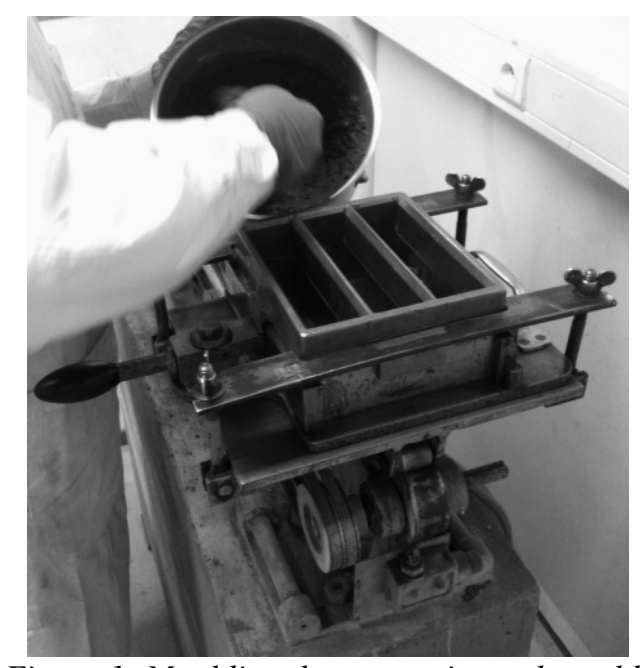

Figure 1- Moulding the mortar in steel moulds

The mortar mixtures were cast into $4 \times 4 \times 16 \mathrm{~cm}$ specimens and cured in a room at $20 \pm 2$ ${ }^{\circ} \mathrm{C}$ at a relative humidity of $92 \%$. After $24 \mathrm{~h}$ the mortar samples were removed and kept into the same room for curing. At each testing age (7 days , 28 days) three specimens from each combination has to be tested for flexion first, then compression.

Observations:

a) During the mixing we observed different things: when we had the maximum percentages of the $\mathrm{CaSO}_{4}$ activator( 13\%) (Figure 2) the mixture was dry; the water decreased and the compaction was difficult.

b) The mixtures with $\mathrm{Na}_{2} \mathrm{SO}_{4}-3 \%$ were liquid (Figure 2); also the samples with $5 \%$ were very liquid. 
6.

МЕЂУНАРОДНА КОНФЕРЕНЦИЈА

Савремена достигнућа у грађевинарству 20. април 2018. Суботица, СРБИЈА

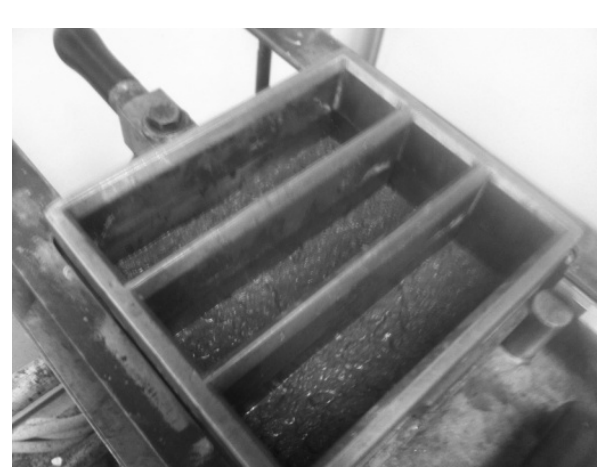

Figure 2 - Mortar with $13 \% \mathrm{CaSO}_{4}$

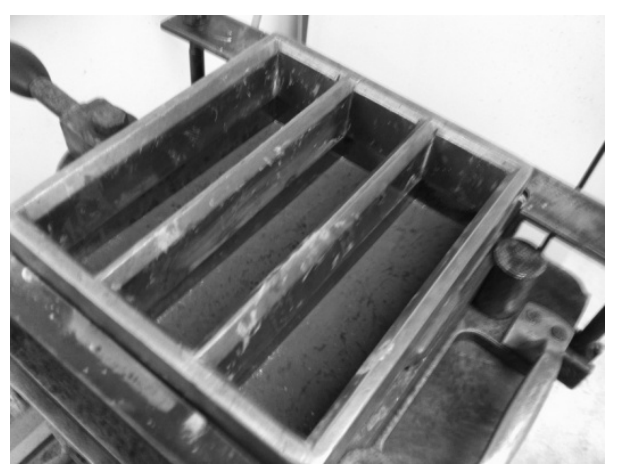

Figure 2 - Mortar with $5 \% \mathrm{Na}_{2} \mathrm{SO}_{4}$

\section{EXPERIMENTAL TESTS}

We weight the samples and made the flexion tests (Figure 3) first and after the compression tests (Figure 4) for 7 and 28 days. The tests were performed using an Instron 5585 machine.

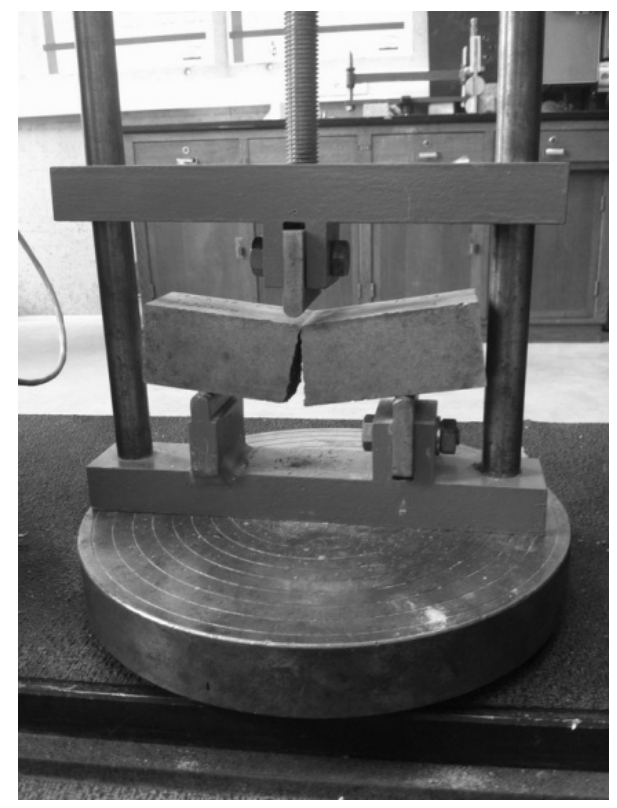

Figure 3 - Flexion test

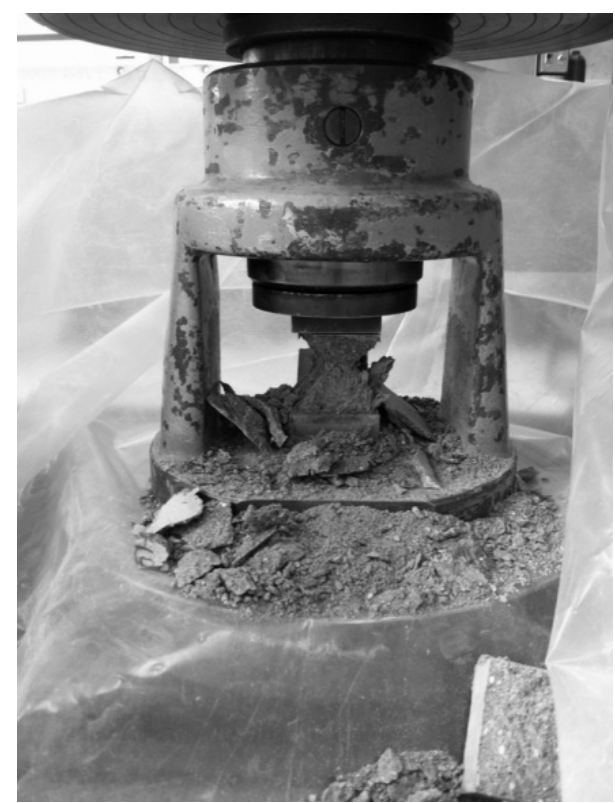

Figure 4 - Compression test 
$6^{\text {th }}$ international CONFERENCE

Contemporary achievements in civil engineering 20. April 2018. Subotica, SERBIA

\section{RESULTS}

Results using Cement CEM 1v2 (30 V 65 K 5 LL)

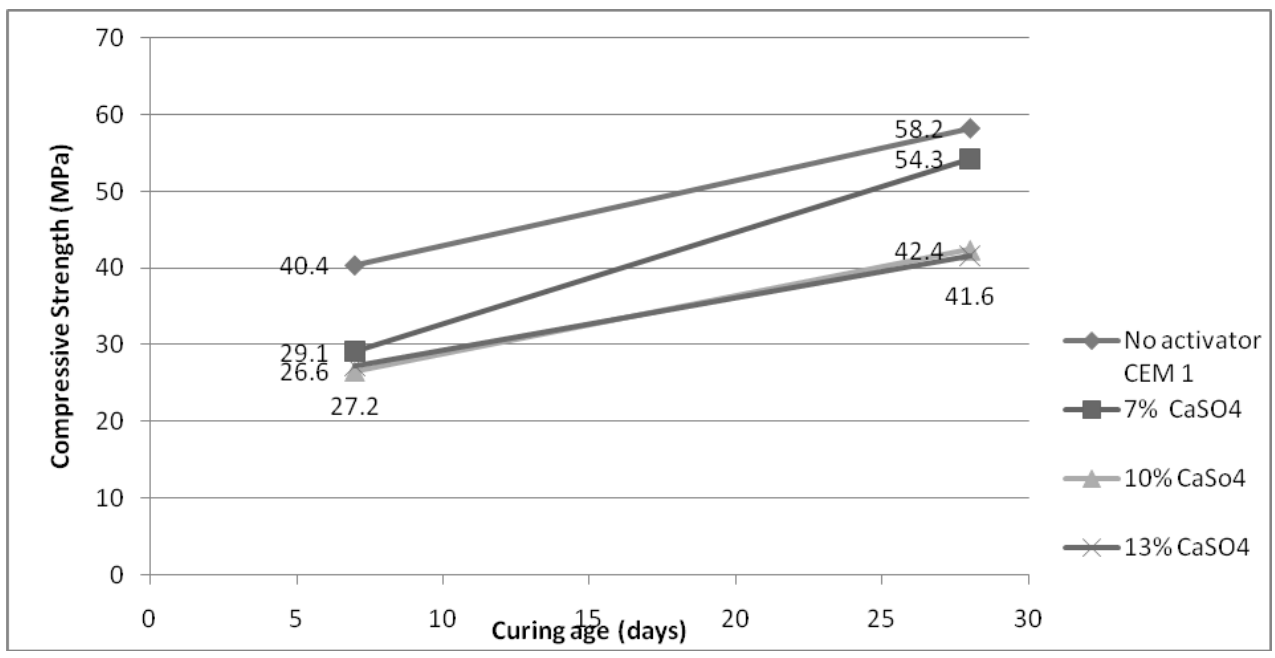

Figure 5 -Compression Results using $\mathrm{CaSO}_{4}$

CEM 1v2

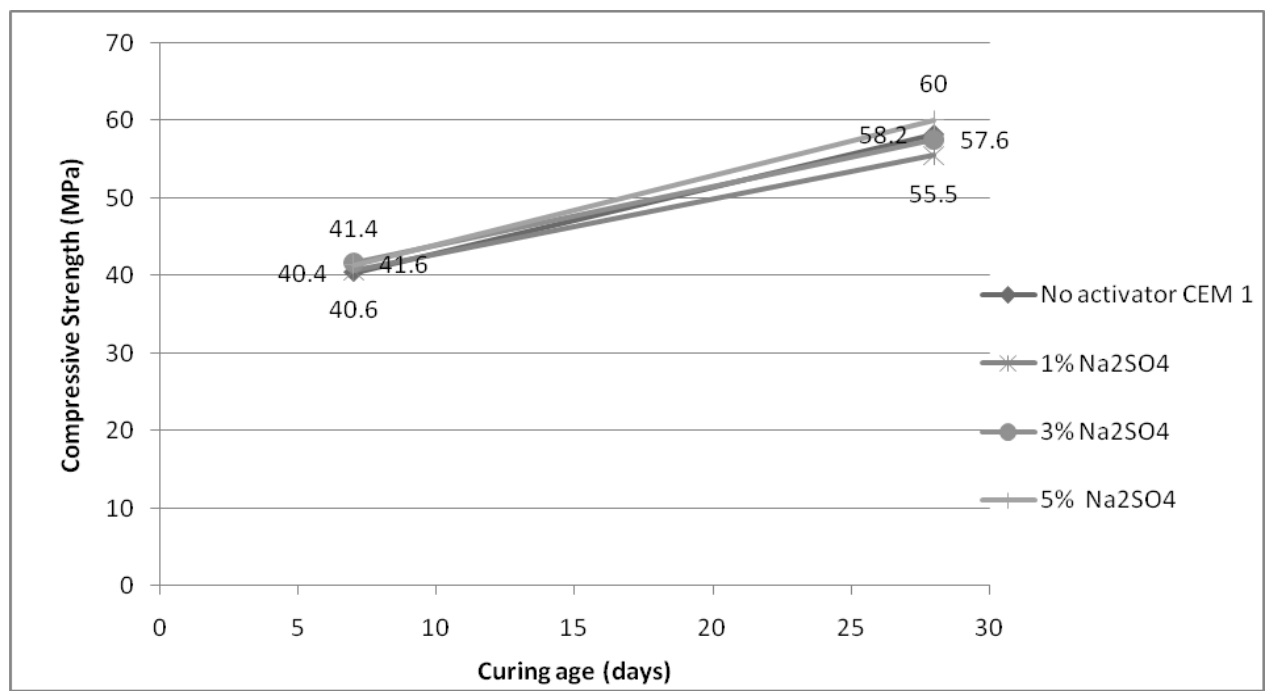

Figure 6 - Compression Results using $\mathrm{Na}_{2} \mathrm{SO}_{4}$

CEM 1v2 
6. МЕЂУНАРОДНА КОНФЕРЕНЦИЈА

Савремена достигнућа у грађевинарству 20. април 2018. Суботица, СРБИЈА

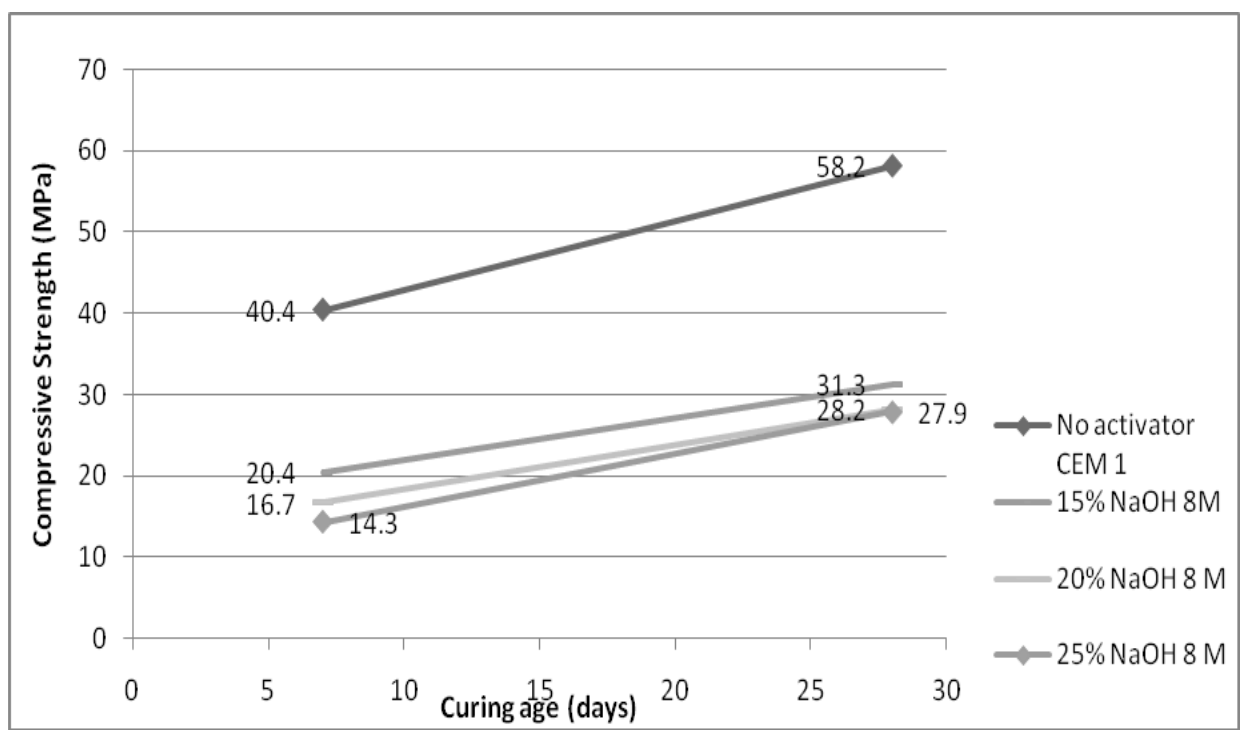

Figure 7 -Compression Results using $\mathrm{NaOH} 8 \mathrm{M}$ CEM 1v2

Results using Cement CEM 12v2 (30 V 35 K 35 LL)

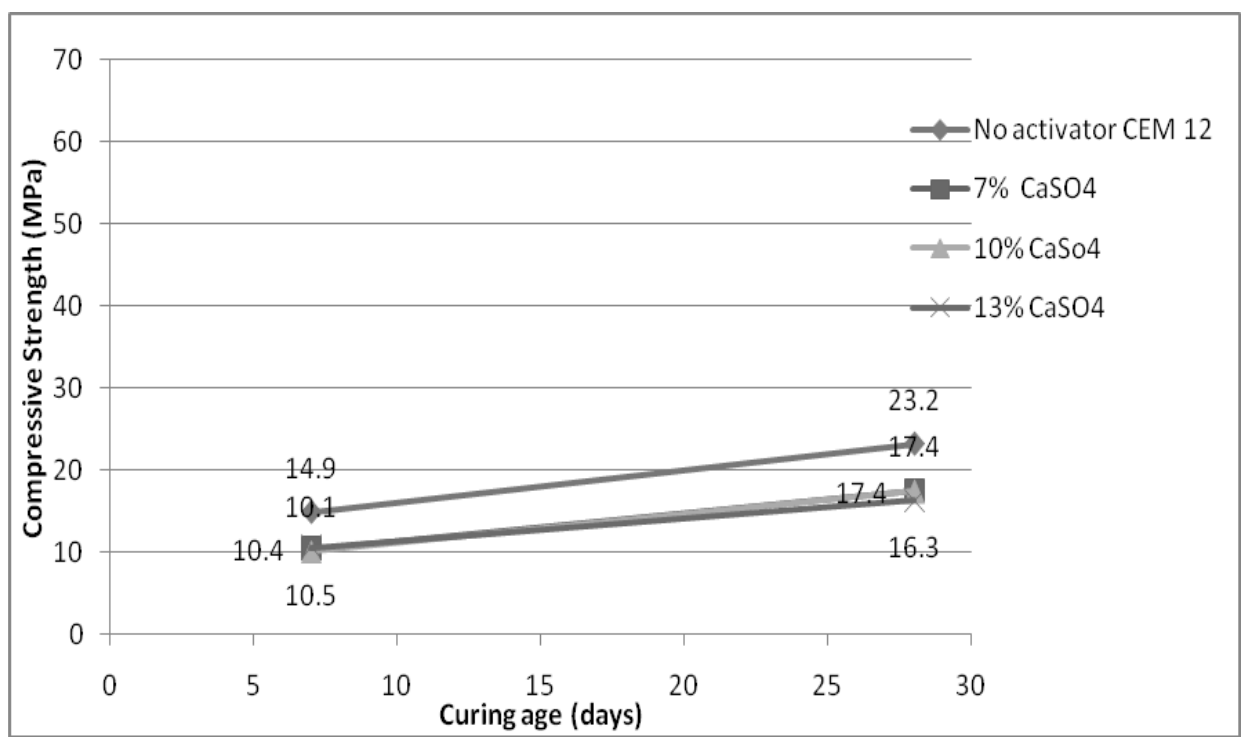

Figure 8 - Compression Results using $\mathrm{CaSO}_{4}$ CEM 12v2 
$6^{\text {th }}$ international Conference

Contemporary achievements in civil engineering 20. April 2018. Subotica, SERBIA

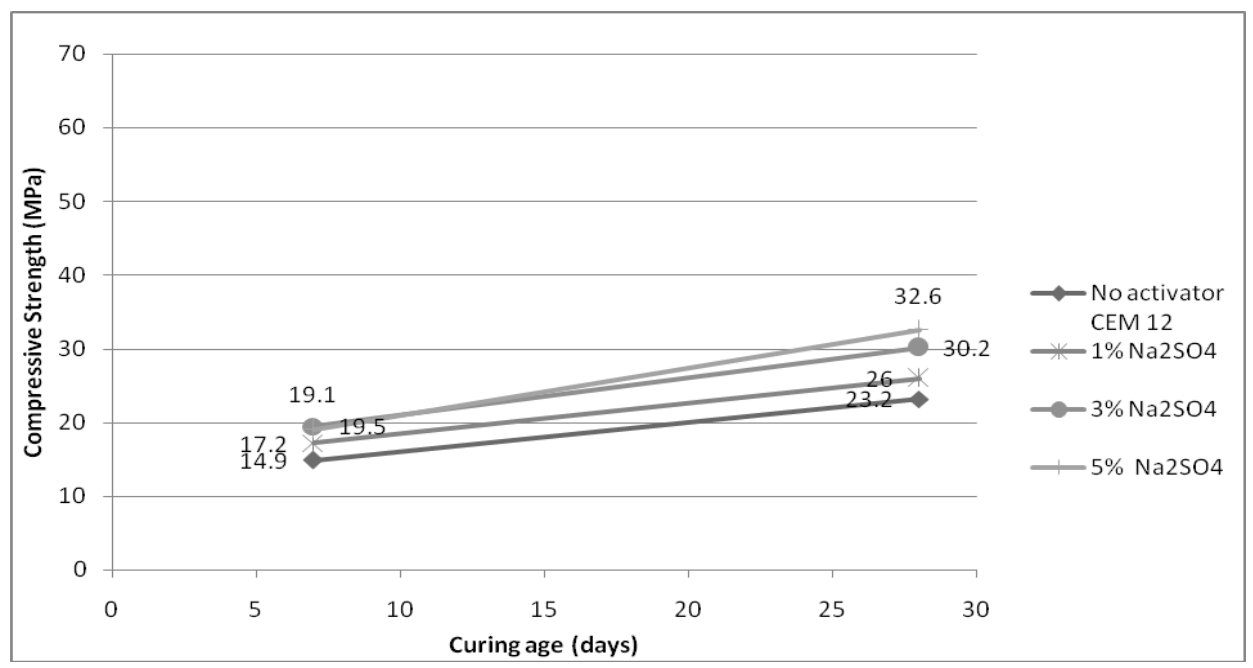

Figure 9 -Compression Results using $\mathrm{Na}_{2} \mathrm{SO}_{4}$

CEM 12v2

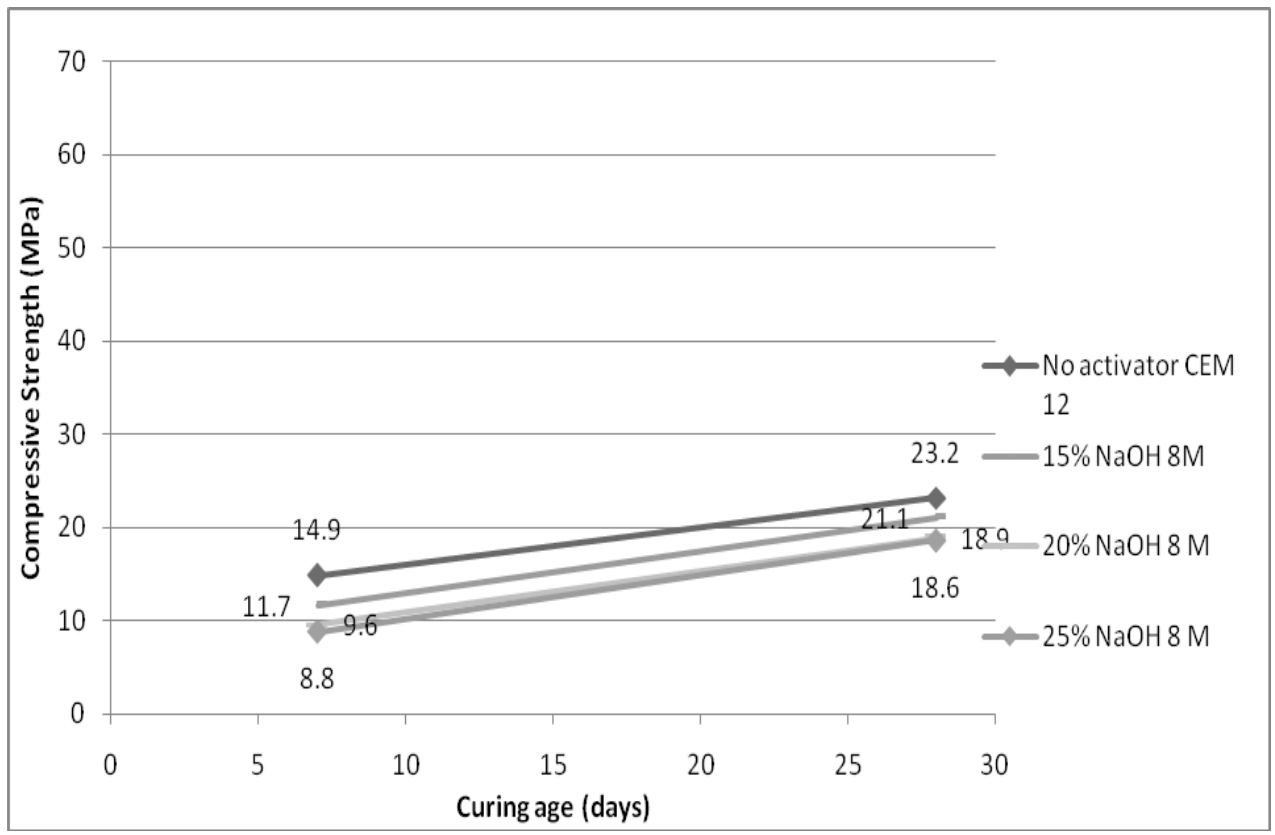

Figure 10 - Compression Results using $\mathrm{NaOH} 8 \mathrm{M}$

CEM $12 v$ 
Савремена достигнућа у грађевинарству 20. април 2018. Суботица, СРБИЈА

\section{CONCLUSIONS}

1. There is a difference between cement CEM 1v2 strength and cement CEM 12v2 strength without any activator at 7 and 28 days which is normal because CEM 1v2 has more clinker (Figure 11).

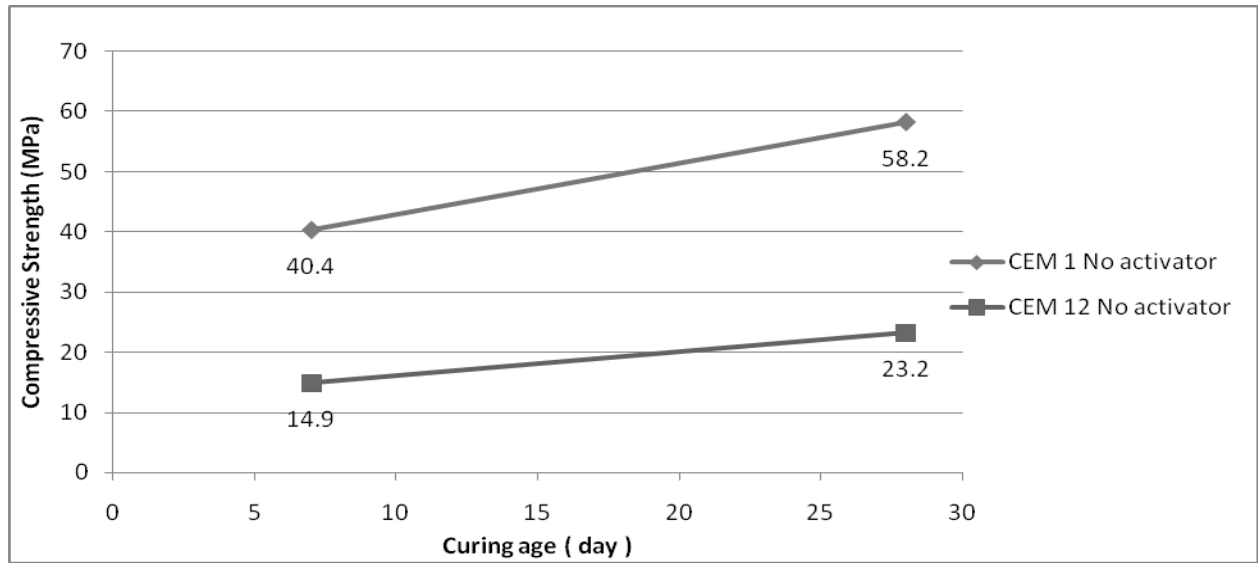

Figure 11 - CEM 1v2 and CEM 12V2 without activator

2. Between these three activators the one with the best results is $\mathrm{Na}_{2} \mathrm{SO}_{4}$ and the best percentage at early age is $3 \%$ of $\mathrm{Na}_{2} \mathrm{SO}_{4}$ (Figure 12) .But the tests at 2 days weren't made yet.

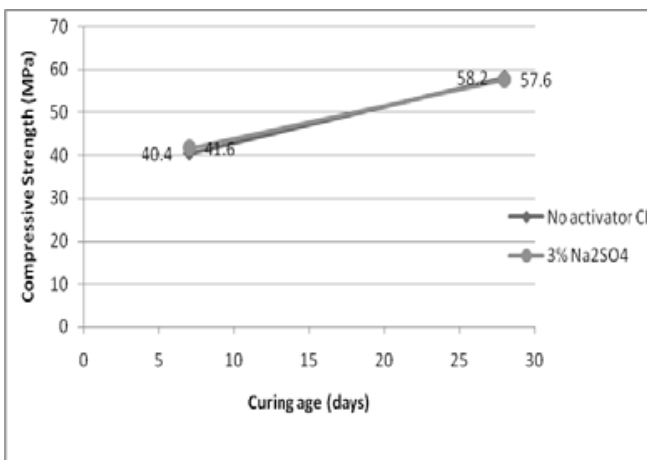

a)

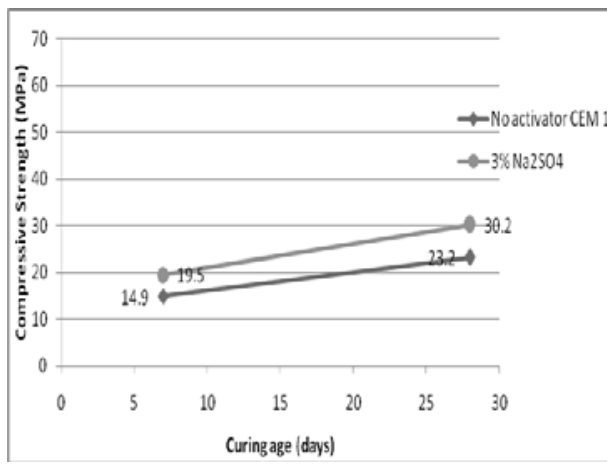

b)

Figure 12 - Mortars with $\left.3 \% \mathrm{Na}_{2} \mathrm{SO}_{4}-a\right)$ CEM 1v2 , b) CEM 12 v2

3. $\mathrm{Na}_{2} \mathrm{SO}_{4}$ offers more strength to the samples in which we used CEM 12v2 because limestone filler also works as an activator for the fly ash.

4. Also the durability and the evolution of the mechanical performances of the concretes have to be studied because using these substances in a wrong proportion may lead in time to the degradation of the concrete. 
$6^{\text {th }}$

INTERNATIONAL CONFERENCE

Contemporary achievements in civil engineering 20. April 2018. Subotica, SERBIA

\section{REFERENCES}

[1] http://www.gemme.ulg.ac.be/

[2] Pierre Mounanga, Muhammad Irfan, Ahmad Khokhar, Raha El Hachem, Ahmed Loukili - Improvement of the early age reactivity of fly ash and blast furnace slag cementitious systems using limestone filler, 2010

[3] A.Xu, S.L.Sarkar, Microstructural study of gypsum activated fly ash hydration in cement paste, Cem.Concr Res. 21,1991

[4] C.J. Shi, Early microstructure development of activated lime-fly ash pastes, 1996

[5] W.Ma, C.Liu, P.W .Brown, S.Komarneni, Pore structures of fly ashes activated by $\mathrm{Ca}(\mathrm{OH})_{2}$ and $\mathrm{CaSO}_{4} * 2 \mathrm{H}_{2} \mathrm{O}, 1995$

[6] C.J. Shi Pozzolanic reaction and microstructure of chemical activated lime - fly ash pastes, ACI Mater.J. 95,1998 